\title{
Economic Justice and the 2003-2010 Recession: Lessons Learned for Multi-Level Social Work Practice
}

\author{
Janice Gasker ${ }^{1}$, Jia $\mathbf{Y u}^{2}$ \\ ${ }^{1}$ Department of Social Work, Kutztown University of Pennsylvania, Kutztown, PA, USA \\ ${ }^{2}$ Department of Economics, Suffolk University, Boston, MA, USA \\ Email: gasker@kutztown.edu, jyu5@suffolk.edu
}

Received 4 October 2014; revised 30 October 2014; accepted 18 November 2014

Copyright (C) 2014 by authors and Scientific Research Publishing Inc.

This work is licensed under the Creative Commons Attribution International License (CC BY). http://creativecommons.org/licenses/by/4.0/

c) (†) Open Access

\begin{abstract}
The pursuit of social justice is a defining value of the social work profession, and its economic component is widely perceived to be an essential component of this quest. Consequently, social workers will practice to their fullest capacities if they understand the contemporary economic phenomena needed to promote social justice on all levels of practice, and discipline-specific knowledge in an accessible format is required to do so. In response, this paper provides a social work perspective on the world-wide recession of 2003-2010 along with implications for micro, mezzo and macro practice.
\end{abstract}

Keywords

Social Justice, Economic Justice, Social Work, Recession

\section{Introduction}

The social work profession's mission is to forward "individual well-being in a social context and the well-being of society” (NASW, 2008: p. 1). Consequently, social justice plays a central role in social work of all kinds (McLaughlin, 2011; CSWE, 2008; NASW, 2008; Lundy \& van Wormer, 2007; Marsh, 2005; IASSW, 2000), and every social worker is expected to develop competency in understanding both social and economic justice (CSWE, 2008). It follows that economic concepts, theories, and contemporary economic phenomena should be firmly embedded in the social work knowledge base, but this is not always the case.

The body of social work literature related to economic justice is well-considered but limited and geared primarily toward the philosophical underpinnings of the profession and their implications for policy and research. 
An interested direct practice social worker finds little to facilitate a practice-specific understanding of economics. In response, this paper's purpose is to provide an accessible picture of the recent economic crisis with a focus on economic justice and the concerns of the social work profession. This analysis will facilitate the direct practitioner's understanding of the impact of the recession on persons and systems served and the appropriate responses to their subsequent needs.

\section{The Recession}

As most Americans know, a great financial crisis emerged in 2005-2007, the ripple effects of which may still be felt. The crisis is believed to have been rooted to a great extent in the housing market (Federal Reserve Education.org, 2014). Sadly, it may be argued by some that US homeowners who defaulted on mortgages played a major role in the economy crisis that impacted the global financial and economic system. More significant blame, however, may lie with the extraordinary conditions that existed in a number of industries, such as finance, education, healthcare, etc. Causes and outcomes of the crisis and subsequent policy developments are considered below.

\subsection{Key Events and Trends-2003-2010}

In the early 2000's the American Dream was within the grasp of more and more Americans. Many of those who could only dream were suddenly able to get mortgages, and these mortgages had relatively low interest rates (Federal Reserve Education.org, 2014). The problematic housing market that is believed to have caused the tipping point in economic growth began around 2003. Demand for houses rose, and as most economists frequently predict in such cases (Case, Fair, \& Oster, 2014), supply may accordingly rise. The rise in supply may follow a rise in demand as an automatic stabilizer in general microeconomics. In other words, when demand goes up, prices go up, suppliers catch the profit-earning opportunities, and more suppliers may enter the housing market. The large amount of suppliers push supply to go up, pushing prices downward again. Eventually, the housing market grows, since both demand and supply grow through the stabilization process. This price stabilizing phenomenon would normally keep the economy on a fairly even keel, which is necessary to continue healthy economic growth and presumably to maintain or improve the quality of life for most Americans.

Unfortunately, during the period immediately preceding the recession, there was unexpected performance in an area of the economy-banks. Banks were in unprecedented condition. At this time, banks were increasingly engaged in the securitization of mortgages, in which mortgages were sold in bundles (securities) that were traded among banks in financial markets. These securities began to include more and more subprime mortgages, i.e. those whose holders had unstable credit records or low credit scores (Federal Reserve Education.org, 2014). In finance, subprime mortgages mean making loans to people who may have difficulty maintaining the repayment schedule, sometimes reflecting setbacks such as unemployment, divorce, medical emergencies, etc. In other words-and significantly for social workers - a part of the fragile economic situation was caused by mortgages that were made to people who had lower credit ratings and were ill-equipped to make the payments. Most importantly, the borrowers did not realize that they could not afford them. Borrowers were approved by banks even when they could not demonstrate an ability to pay in the reliable ways that had been common practice in lending for years. From a strengths perspective, one might consider that these people were striving to better themselves from a personal finance standpoint: they were seeking to stop losing money through rent and invest in a property that would not only provide a home but would also be a wise investment.

\subsection{Predatory Lending}

As banks traded more and more mortgage-based securities, their management systems began to register concern about the high risk mortgages and peoples' ability to pay back. Concerns about risk led banks to increase mortgage interest rates sharply. Rising interest rates on mortgages and other consumer credit have a powerful impact, resulting in a shortage of money or credit. Consequently, the economic downturn has come to be called a "credit crunch... a severe shortage of money or credit” (British Broadcasting Corporation, 2009). When interest rates rise, people borrow less, leading to a shortage of money, and-in the case of the market for homes-shrinking demand for houses and plummeting price levels. This occurred in a sudden and drastic way with devastating impact. Figure 1 shows the trend of Case-Shiller Home Price Index from 2006 to 2013 quarterly (Standard \& 


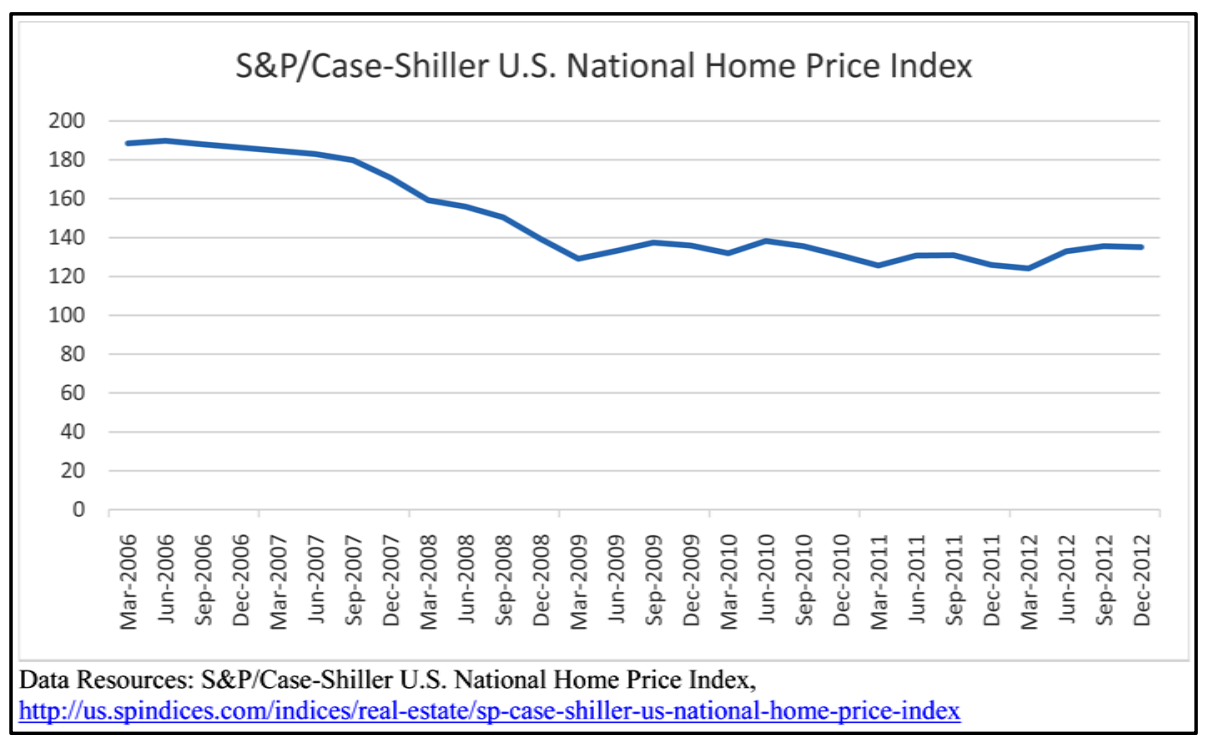

Figure 1. S \& P/Case-Shiller US National Home Price Index.

Poor, 2014). We can see that the Case-Shiller Home Price Index reported that prices fell 40\% from 2006 to mid2009 (Chang, 2009). Falling prices left homeowners underwater, meaning their homes were worth less than they owed on the mortgages, since the mortgage interest rates were rising at the same time. It is apparent that another unexpected economic element at this time was a phenomenon many call predatory lending. In general, predatory lending is the unfair, deceptive, or fraudulent practices of some lenders during the loan origination process. The victims of predatory lending are not only people who have lower credit ratings and can only qualify for subprime mortgages, they are also people who qualify for prime mortgages and are simply lacking the financial literacy required to evaluate their options. In the housing market, predatory lending is a practice in which mortgage companies and banks prey on those who believe they can purchase homes when in fact they do not realize that they may not be able to afford the mortgage payments. Low down payments and adjustable rate mortgages - where people pay less per month immediately after acquiring the loan then much more later-were obvious culprits (Chang, 2009). In short, large numbers of people are believed to have been deceived by financial institutions that were under the regulation of the US government and Federal Reserve, a condition complicated by the fact that laws governing predatory lending vary from state to state. When those homeowners found they could not change the terms of their mortgages, acquire new mortgages, or pay their current ones, they found they owed more than their homes were worth on the real estate market. If they sold, they would be left with crippling mortgage debt along with new housing expenses. Home prices were simply too low. Past banking practice used to include the idea of a "short sale", in which the bank accepted the selling price in lieu of a payment in full, but in the wake of the crisis, they sharply curtailed this practice. Consequently, many individuals and families were forced to stop paying their mortgages-they defaulted. In some cases, working families ended up homeless, with no credit to support a new apartment lease.

\subsection{Rising Unemployment}

It would be expected that as large numbers of mortgages went unpaid and prices fell, the business of construction would fail and workers would be laid off. They would be expected to consume less, causing other industries to fall. These trends did occur. In a report commissioned by Congress, the US Accountability Office found that the number of mortgages in default increased 50\% from June 2005 to June 2007: more than 1 million were in default or foreclosure in 2007 (US Government Accountability Office, 2007). The overall health of the economy began to suffer as well. The US Gross Domestic Product (GDP), a measure of the annual production of final goods and services produced by a country in a year or over a given period of time, rose $4 \%$ in 2004, 3\% in 2005 and 2006, 2\% in 2007, and finally began to actually fall in 2008, shown in Figure 2 (The World Bank, 2014).

In such a situation, the labor market—a major input into the circular flow of economic activity—-would be expected to suffer from low demand and result in unemployment. This trend, too, occurred. It is too simple to 


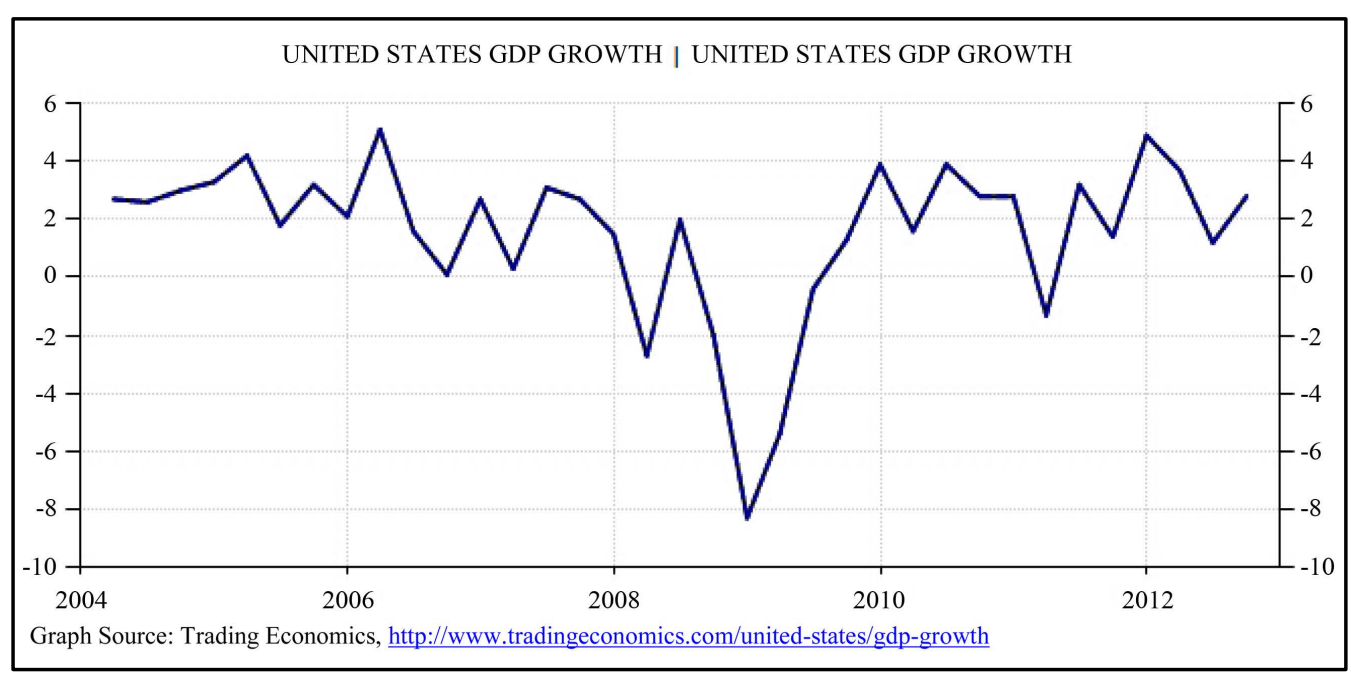

Figure 2. US GDP growth rate 2004-2012.

report only unemployment rates to illustrate the health of the labor market, as there are many problems measuring trends in the labor force. The overall unemployment rate- the percentage frequently reported in the mediatraditionally refers to persons who are actively looking for work. The measure does not include those who have accepted fewer hours or lower wages than they expected simply because they felt compelled to do so when they could not find other work. Because these people are employed for wages, they are not considered to be unemployed but under employed. They do not appear in counts of overall unemployment. In addition, there are those workers who, after seeking employment in vain for a period of time, simply give up. These workers-known as discouraged workers - do not appear in the unemployment rates most widely publicized by the Bureau of Labor Statistics. A further complication of measuring unemployment is that severe periods of prolonged unemployment can cause increasing numbers of laborers to become discouraged. Paradoxically, this phenomenon may serve to push the traditional unemployment rate downward (Case, Fair, \& Oster, 2014). In other words, as the economy worsened over time more people began to take jobs that could not sustain them financially, and increasing numbers of laborers simply chose to give up. As a result, the publicized unemployment rate actually made the situation appear to be much better than it actually was.

Rather than overall unemployment, labor force participation may be best measured in this circumstance by combining counts of those who are unemployed as well as those who are discouraged. This count reveals a grim picture for 2003-2009. Figure 3 shows the overall unemployment rate from 2008 to 2012. The unemployment rate for the US labor force and those marginally attached to it over the age of 16 was fairly steady up through much of 2008 (around 5\% - 6\%). In August of 2008, it began to rise over 6\%, and by December of that year it was $7.3 \%$ The year 2009 was characterized by dramatic increases: 7.8\% in January, 9\% in April, and over 10\% in October through December 2009. During the whole of 2010 the rate has exceeded 9.5\% and continued between 9\% and 9.5\% all the way through September of 2012 (Bureau of Labor Statistics, 2014). Given that full employment (a predicable rate of unemployment that is expected in a healthy economy) is estimated to be about $4 \%$, unemployment rates during this time were catastrophic. During the period of crisis, the low income families that experienced predatory lending were again in jeopardy: they faced increasing chances to lose their jobs and had little financial cushion to bear the income loss. As social workers, we are aware of the dramatic and pervasive impact of this type of economic insecurity on individuals and families.

Meanwhile, it had become difficult for financial institutions to calculate the risk level of individual mortgages since they had been packaged as securities, or bundles of mortgages anonymously lumped together, a situation that was made worse by complex financial instruments that few people understood. As information and risk analysis among banks become more and more asymmetric, they hesitated to lend among themselves. Finally, left without income from mortgages and without borrowing power to make more loans, banks began to fall into bankruptcy. These dominoes began to fall in 2008, with the bankrupt of Lehman Brothers and the collapse of Washington Mutual (Federal Reserve Education.org, 2014). All banks began to tighten credit standards and demanded increasingly higher interest, ushering in the credit crunch (Federal Reserve Education.org, 2014). 
Households borrowed less, spent less, and contributed to the slowdown of both consumer spending and the economy's services and products, or its aggregate output.

\section{Key Events of the Credit Crisis around 2006}

Several events were pivotal to the credit crisis around 2006. The most significant occurred in April, when US home prices peaked and then rapidly dropped (Chang, 2011; Economics of Crisis, 2010; USA Today, 2011). As noted above, a jump in subprime mortgages began after 2003, marked by a steady increase in the Debt Payments-to-Income ratio (Levy Economics Institute of Bard College, 2008). In other words, in 2006, it was much harder to pay back mortgages for people who were eligible to receive them. Here was an opportunity for social workers to have advocated for a stop to predatory lending. If workers had been aware of their client's household budgets, they may have understood the potential disaster inherent in oversized mortgage commitments, but many agencies and workers do not include budgeting skills in regular assessments.

As mortgage holders and the overall US national economy faltered, the global impact was profound. Finally, March 20-26 of 2006 marked what has been called a major world crisis including, but not limited to, a loss of confidence in the dollar, a crisis of US financial imbalance, and a crisis in American leadership. It was feared during this period that only a concerted American effort would avoid hostilities in Iran, and it was expected that this effort would not occur. Americans, it was believed, were placing all of their attention on their own economic problems. Political upheaval was extraordinary in the Middle East (NewropMag, 2006).

\subsection{Long Term Effects on the US Economy}

The effect of these events was a long-lasting recession—a period of decline in overall aggregate output. Technically, an economic decline may be called a recession after two consecutive quarters (Case, Fair, \& Oster, 2014). However, this particular decline has lasted for several years. The National Bureau of Economic Research named December 2007 as the beginning of the contraction and, as noted above in Figure 2, the US GDP growth fell below 0\% in 2008 for the first time (BBC, 2009; World Bank, 2014). As the credit crunch caused aggregate demand to fall, aggregate output fell, unemployment rose... demand fell even more. The economy was in a vicious cycle. It was not until 2010 that the growth of GDP finally began to slowly rise: $2.5 \%$ in $2010,1.8 \%$ in 2011 , $2.8 \%$ in 2012.

Perhaps most troubling is the toll the recession has taken on the American middle and working classes. Why were some Americans protected from the recession? By 2012, persons whose wealth was in the stock market were able to bounce back. Those whose wealth was primarily in housing have yet to recuperate. Direct service social workers should be aware that the implications of the crisis include the fact that financial literacy skills will be essential for individuals and families for years to come. For social workers interested in advocacy, it is important to know that real wages continue to be eroded (nearly 1 percent for men and 3 percent for women during 2010 alone), and mean household income was lower in 2011 than in 1996 (Stiglitz, 2012).

\subsection{US Efforts to Revive the Economy-Fiscal and Monetary Policy}

Fiscal Policy. In the wake of the recession, the US Federal Government responded with both of its major tools for recovery, fiscal and monetary policy. Changes in fiscal policy occur directly on the federal government level. Discretionary fiscal policy involves two economic influences: purposeful changes in government spending and revenue collection (taxation) (Case, Fair, \& Oster, 2014). According to Keynesian economics, when the government changes the levels of taxation and government spending, it affects aggregate demand and the level of economic activity. In a situation like a recession, it is often the case that governments engage in expansionary policy. The expansionary fiscal policy is designed to close a recessionary gap by changing aggregate expenditures and shifting the aggregate demand curve, such as an increase in government purchase and transfer payments or a decrease in taxation.

Monetary Policy. In contrast, monetary policy refers specifically to acts of the Federal Reserve, commonly known as the "Fed" (Federal Reserve, retrieved March 30, 2014). These monetary policy actions include the purchase and sale of government bonds, the modification of discount rate (the interest rate charged to commercial banks and other depository institutions of loans received from the Federal Reserve Banks), and reserve requirements, or reserve ratio (the percentage of banks' monetary resources that must remain in reserve) (Case, Fair and Oster, 2014; Federal Reserve, retrieved March 30, 2014). The official goals for monetary policy are to 
stabilize prices and lower unemployment rates. Expansionary monetary policy increases the total supply of money in the economy more rapidly than usual and is a very classic tool to combat unemployment in a recession by lowering interest rates. Specific fiscal and monetary policy changes were extraordinary.

US Fiscal Policy Responses to the Crisis. Fiscal policy developed in response to the recession was dramatic in its magnitude. Federal government action involved both government spending and tax cuts. These policies are exemplified by the American Recovery and Reinvestment Act of 2009.

American Recovery and Reinvestment Act of 2009. In some ways, the American Recovery and Reinvestment Act of 2009 ("the stimulus") resemble the radical programs of FDR's New Deal. Like the Social Security Act of 1935 with its benefits for aging or disabled workers and their dependents along with its initiation of the first federal unemployment benefits, the 2009 stimulus was essentially an expansionary fiscal policy. Expansionary fiscal policy is used to address business-cycle instability that give rises to the problem of unemployment, that is, to close a recessionary gap, which exists if the existing level of aggregate production is less than what would be produced with the full employment of resources. An expansionary fiscal policy is a response to a situation where the Aggregate Supply Curve is nearly flat-that is to say that the economy is not producing near its capacity, in other words, short-run equilibrium level of real production is less than full employment (Case, Fair, \& Oster, 2014). The Aggregate Supply Curve is an important measure here: during this period of a lack of growth in the supply of goods and services the Aggregate Supply Curve demonstrates that theoretically every $\$ 1$ spent by the government results in more than $\$ 1$ expansion in the economy.

In the case of the stimulus of 2009, the government responded with to the crisis with an unprecedented, massive spending policy to increase income and subsequently to increase consumption of goods and services. The stimulus involved huge government spending along with tax cuts: \$288 billion in tax cuts and \$224 billion in government spending with another $\$ 275$ billion of spending in assorted grants and supported loans (Recovery.gov, retrieved March 30, 2014). The goals of the stimulus were to "create and save jobs and to spur economic activity and invest in long-term growth” (Recovery.gov, 2014: para. 1). It is important for the social worker to note that this type of policy is initiated in a belief that the economy will recover from a downturn; expansionary policies are not necessarily initiated simply to help deserving people. As a result, policy makers do not measure the success of policy based on quality of life for vulnerable populations. Policy success is evaluated using economic measures like the Gross National Product (GNP). Consequently, it becomes the social worker's task to educate policy makers about the human cost of economic crisis. The human cost of economic crisis has been taken up by some economists, however. Support for the idea of measuring economic growth through mechanisms other than the GDP may be found in the work of Sen (1992), Stiglitz (2012) and others. Nussbaum, for example, suggests that a measure like the GDP is a resource-based approach to well being and as such does not "tell us enough about how people are really doing. It could give high marks to a nation that ignores the protests of marginalized or subordinated groups". She suggests referencing the Human Development Index as developed by the United Nations. The HDI is a compilation of a series of measures including life expectancy, educational attainment, and GDP per capita (Nussbaum, 2011: p. 58).

The process of stimulus and recovery. Stimulus funds are distributed through 28 Federal agencies through State and Local government, and on to academic institutions, firms, and organizations. In other words, economic stimulus funds begin at the federal level and are passed to businesses whose bids are accepted by federal evaluators. These funds are then used to hire the labor needed to carry out the proposed activity, and these workers receive income that reflects an even higher amount of disposable income than they might expect, given the presence of tax credits that travel the same route as other stimulus funds but go directly to households (Recovery.gov, 2014). In theory, this scenario has what is known as a multiplier effect on the economy (Case, Fair, \& Oster, 2014). Because workers use their disposable income to purchase goods and services, aggregate demand is expected to go up, causing firms' increased productivities with associated increases in labor demand, i.e. dropping levels of unemployment. This is the situation mentioned above, in which every dollar spent by the government results in more than one dollar increase of whole economy. For the social work advocate, it may be stated like this: "When the economy has slowed so much that supply is not growing, the Aggregate Supply Curve is flat and the multiplier effect of government spending is at its greatest."

To date, the stimulus appears to have influenced increases in GDP and decreases in unemployment, albeit much more slowly than has been hoped. The GDP stopped shrinking in 2010, rising 2.5\%, then continued modest growth: 1.8\% in 2011 and 2.8\% in 2012 (World Bank, 2014). Likewise, the unemployment rate for both unemployed and discouraged workers improved slowly (Figure 3). After its peak in 2010 and continued high le- 


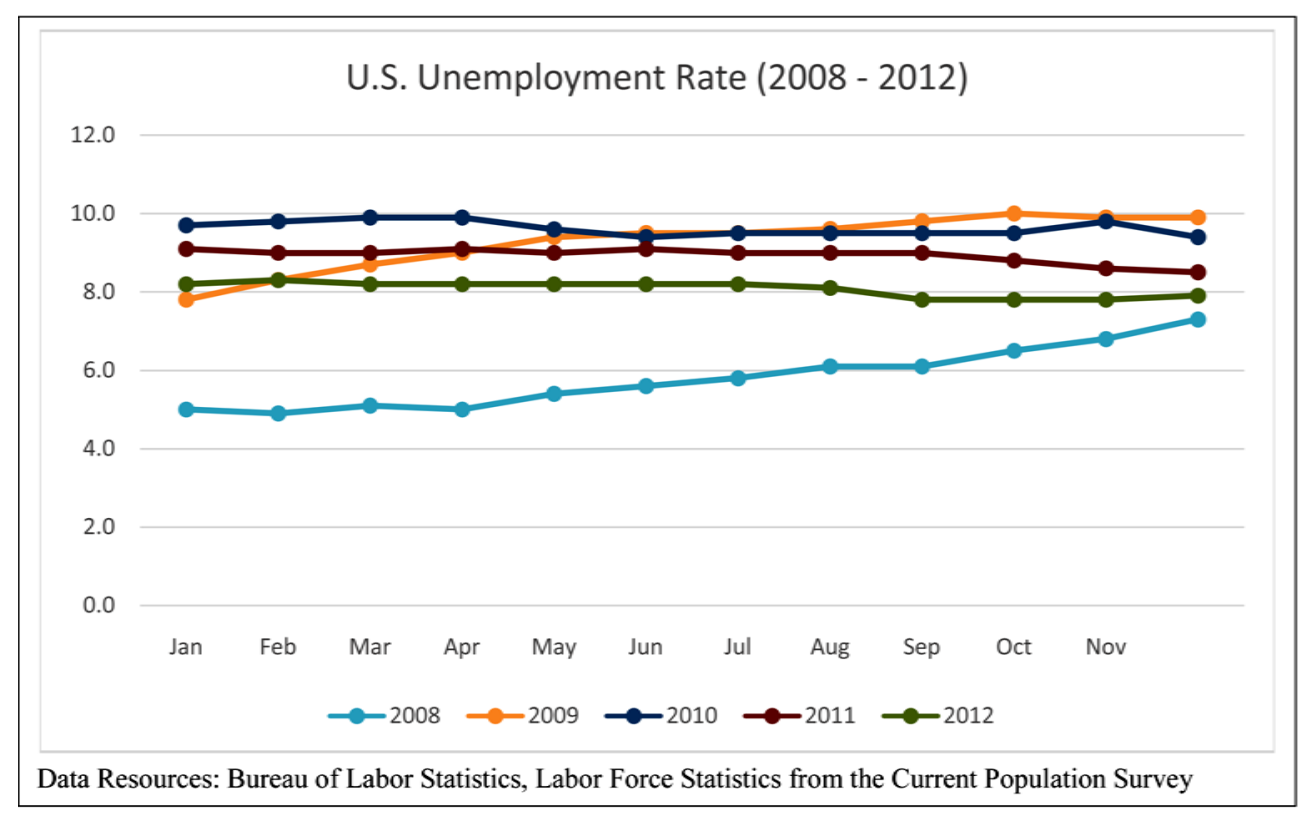

Figure 3. US national unemployment rate 2008-2012.

vels of $9 \%-10 \%$ in subsequent months, the overall unemployment rate began to slowly fall beginning September 2012, continuing around 8\% from November 2013 through February of 2014 (Bureau of Labor Statistics, 2014).

Another aspect of the stimulus that is important from a social work perspective is that the stimulus was intended to require a new level of accountability from recipients of benefits. For example, federal agencies are required to report their fund distribution weekly (Recovery.gov, 2014: para. 2).

US Monetary Policy Responses to the Crisis. Like fiscal policy, monetary policy changes were dramatic. The Federal Open Market Committee (FOMC) — the decision-making section of the Federal Reserve-used all of its available tools to impact the economy. In addition to the purchase and sale of government bonds in the open market, changes in the federal interest rate (in 2008 its lowest for 50 years), and changes in reserve requirements, the Federal Reserve created new methods of influence (Federal Reserve, 2014a; Federal Reserve Education.org, 2014). For example, the Federal Reserve increased its interest rate in 2004. Then, from 2005 to the present, the interest rate was lowered steadily and significantly, with dramatic reductions from 2004 to 2008. After 2008 the downward trend continued but at a much more modest level. In addition, to counterbalance these changes, reserve requirements went from 47.6\% in 2003 to 89\% in 2014 (Federal Reserve, 2014). The Federal Reserve was making money more available through the purchase of government bonds (essentially lending money to the government) while attempting to stabilize banks by insisting that they keep money aside to cover any deposits that may be demanded.

The Federal Reserve's Asset Purchase Program. During the crisis, the Federal Reserve used the open market to increase the supply of money and counter the effects of the credit crunch. In 2008, it began bailing out large financial institutions, beginning with Bear Stearns, and participated in a government takeover of the Federal National Mortgage Association. In 2009, the Federal Reserve took the extraordinary step of buying mortgagebacked securities from private banks that were carrying them at great risk (Case, Fair, \& Oster, 2014). Then, on November 3, 2010, the decision was made by the FOMC to direct the New York Federal Reserve Open Market Trading Desk to purchase $\$ 600$ billion of securities between then and 2011. This served to convert mortgage-backed securities into Treasury securities (Federal Reserve Bank of New York, n.d.). In other words, it was the US Government that was taking up the risk incurred by banks who had participated in predatory lending.

\section{The Impact of Fiscal and Monetary Policies-2003-2014}

The fiscal and monetary policies implemented by the US Government and the Federal Reserve did in fact have a significant impact: the recession ended. As seen above, the GDP stopped shrinking in 2010 and has trended up- 
ward ever since. While the number of weeks US workers over 16 years of age continued unemployed to an unfortunate upward trend from 2004 to 2011, finally there has been a sustainable change. The overall unemployment rate moved from a high of 9.9\% in November of 2009 and March and April of 2010 to a downward trend that began in late 2011 (8.5\% in December 2011) and continues through the present, 6.3\% in May 2014 (Bureau of Labor Statistics, retrieved May 31, 2014). So far, however, the gains have not been sufficient. The recession has contributed to income and wealth inequality. Real income and wealth (adjusted for inflation) have steadily increased for the fortunate, or those who had wealth tucked away in the stock and bond market instead of primarily in their homes. At the same time, the persons in the bottom fourth on the US income scale have seen their wealth decrease from negative $\$ 2300$ (meaning debt of \$2300) pre-crisis to negative $\$ 12,800$ (average debt of $\$ 12,800$ ) post-crisis (Stiglitz, 2012). Certainly there are many reasons for those changes, but the recession is widely believed to play a significant role, and the Nobel prize-winning economist Stiglitz (2012) has suggested that growing inequity is resulting in negative consequences ranging from reduced life expectancy for the disadvantaged to lower educational attainment and overall well-being for our clients. In addition, it has been suggested that the inequity in America is undermining the "freedom to achieve" that has been the hallmark of American society since the country’s inception (Sen, 1992: p. 129).

\section{Impact on the Global Economy}

As seen above, the US financial crisis marked what was feared to be a world crisis related to American finances and leadership (NewsMag, 2006). Due to the interaction of world banks, the defaults by mortgage payers resulted in debt worldwide. Between 2007 and 2008, many other countries' GDP growth percentages reveal shrinkage in their economies: France $2.3 \%$ to $-0.1 \%$; Greece $3.5 \%$ to $-0.2 \%$; Ireland $5.0 \%$ to $-2.2 \%$; Italy $1.7 \%$ to $-1.2 \%$ (The World Bank, 2014). As worries about the solvency of banks and other financial institutions grew, stock markets worldwide fell drastically (Chang, 2009). Given the person-in-environment perspective, social workers are better positioned than most to articulate the potential biopsychosocial impact on individuals that results from the increasingly globalized nature of the world economy.

\section{Conclusion}

Financial institutions, such as banks and a lack of regulation played a significant role in the US, and ultimately the global, financial crisis. Also to blame may be the political unrest that lead to uncertainties of the future. Not least are predatory lending practices toward those Americans who simply wanted to achieve the American Dream. Facing unemployment and unmanageable debt, these middle- and working-class homeowners were forced to default on mortgages they could not afford in the first place. Many of those who experienced owning a home for the first time had only a brief taste of what realtors call "pride in ownership." In the wake of the worst economic crisis since 1929, perhaps these members of the labor force may be considered to be the biggest losers of all.

\section{Social Work Practice Implications}

Why do social workers need to know all of this? Beyond the demands of responsible citizenship, social workers are committed to social and economic justice. Ideally, that commitment manifests directly in practice. On the micro level, workers should consider a regular practice of probing in-depth for financial information in the intake process. The financial strengths and needs of individuals must be a concern of every practitioner in every field of practice. The recent recession has highlighted the vulnerability of individuals who seek to buy homes. During an assessment with a component related to personal finance, a social worker may note that the client may be taking out a mortgage when their employment was likely to be at risk or a mortgage that was simply beyond their current budget, particularly when real estate taxes were factored in. Early recognition of the potential for financial problems is critical, as early financial counseling has been found to "significantly improve the likelihood of positive outcomes” (Wollen \& Bauer, 1990: p. 156).

In addition, customary client assessment practices should include evaluation of clients' financial literacy. Training or referral for services related to budgeting, banking and financial planning should be a usual part of practice with individuals in any setting.

On the mezzo level of practice, it must be considered that the families social workers serve may bear the con- 
sequences of predatory lending practices for years to come. Family assessment, therefore, should have similar components as those of individual clients, taking into account a number of additional factors. Family assessment should consider family-level financial literacy, or the ability of the family to share knowledge as well as resources. How adept are adults at providing experiences for children in which they experience planful money management? It is significant to note that the ability of parents to provide financial instruction has been empirically demonstrated to be associated with successful payments while a lack of financial literacy in parents has been associated with increasing levels of loan delinquency and foreclosure (Grinstein-Weiss, Spader, Yeo, Key, \& Freeze, 2012). The assessment of family-level financial literacy may also uncover the potential for financial abuse, particularly for older people and their family members (Wilson, Tilse, Setterlund, \& Rosenman, 2009). In addition, the social worker must also examine budget-making processes within the family; it may take more than one financially competent family member to create family sustainability. Finally, work on the mezzo level requires assessment of the family power dynamics that influence budgets and spending/saving priorities.

On the macro level, social workers across the board must develop a knowledge base related to financial and economic literacy. This knowledge is clearly necessary to carry out much-needed advocacy to address the evergrowing inequities in American society. For example, Caplan (2014) reports that some communities have successfully protected themselves from financial marginalization and predatory lending through community-based financial alternatives such as community development financial institutions that broaden lending capacity and lending circles in which a group of people contribute to a fund that provides loans for the group members. Alternatives such as these can help communities avoid practices that are known to be detrimental: the fringe economy's harmful pawnshops and payday/tax refund lenders (Karger, 2005).

It is essential that social workers on all levels of practice stay aware of economic trends. Potential actions toward this end include continuing education requirements related to economic processes and financial capability and asset building; stronger educational program accreditation requirements specifically related to competency in financial and economic literacy; and focused university-level training for faculty as well as students. It has been demonstrated that social workers who receive formal training in "financial social work" are able to help clients with financial issues; these social workers were also found to be "not immune from experiencing some of the same financial problems that confront their clients" (Despard \& Chowa, 2013: p. 699). With a strong economic and financial knowledge base, social workers will be effective agents for social and economic change in ways that will benefit all people...including ourselves.

\section{References}

Board of Governors of the Federal Reserve (2014a). Open Market Operations. Washington DC: Author. http://www.federalreserve.gov/monetarypolicy/openmarket.htm

British Broadcasting Corporation (2009). Timeline: Credit Crunch to Downturn. 7 August 2009. http://news.bbc.co.uk/2/hi/business/7521250.stm

Bureau of Labor Statistics (2014). Labor Force Statistics from the Current Populations Survey: Total Unemployed Plus Discouraged. Washington DC: Author. http://data.bls.gov/pdq/SurveyOutputServlet

Caplan, M. A. (2014). Communities Respond to Predatory Lending. Social Work, 59, 149-156. http://dx.doi.org/10.1093/sw/swu008

Case, K. E., Fair, R. C., \& Oster, S. M. (2014). Principles of Macroeconomics (11th ed.). New York: Pearson.

Chang, W.W. (2011). Financial Crisis of 2007-2010. Buffalo, NY: State University of New York at Buffalo. 2011.pbfeam-019-2.doc

Despard, M. R., \& Chowa, G. A. N. (2013). Training Social Workers in Personal Finance: An Exploratory Study. Journal of Social Work Education, 49, 689-700.

Economics of Crisis (2010). The Great Contraction: Timeline of Events. www.economicsofcrisis.com/timeline.html

Federal Reserve Bank of New York (n.d.). \$600 Billion Treasury Large-Scale Asset Purchase Program. www.newyorkfed.org/markets/fast facts lsap.html

Federal Reserve Education (2014). 2006 and Beyond: Financial Crisis and Response. http://www.federalreserveeducation.org/about-the-fed-history/2006andbeyond.cfm

Granruth, L. B. (2009). Justice Implications of the Proposed Federal Family and Work Tax Credits: Applying Justice Theories to Policy Advocacy. Families in Society: The Journal of Contemporary Social Services, 90, 205-211.

http://dx.doi.org/10.1606/1044-3894.3875 
Grinstein-Weiss, M., Spader, J. S., Yeo, Y., Key, C. C., \& Freeze, E. (2012). Loan Performance among Low-Income Households: Does Prior Parental Teaching of Money Management Matter? Social Work, 36, 257-270. http://dx.doi.org/10.1093/swr/svs016

Karger, H. J. (2005). Credit and Financial Services in America’s Fringe Economy. Social Development Issues, 27, 86-101.

Lundy, C., \& van Wormer, K. (2007). Social Justice, Human Rights, and Peace: The Challenge for Social Work in Canada and the USA. International Social Work, 50, 727-739. http://dx.doi.org/10.1177/0020872807081899

Marsh, J. (2005). Social Justice: Social Work’s Organizing Value. National Association of Social Workers, 50, $294-294$.

McLaughlin, A. M. (2011). Exploring Social Justice for Clinical Social Work Practice. Smith College Studies in Social Work, 81, 234-251. http://dx.doi.org/10.1080/00377317.2011.588551

National Association of Social Workers (2008). Code of Ethics of the National Association of Social Workers. Washington DC: National Association of Social Workers.

Sen, A. (1992). Inequality Re-examined. New York: Harvard University Press.

Sen, A. (1992). Inequality Re-Examined. Cambridge, MA: Harvard University Press.

Standard, \& Poor, D. J. I. (2014). S\&P/Case-Shiller US National Home Price Index. http://us.spindices.com/indices/real-estate/sp-case-shiller-us-national-home-price-index

Stiglitz, J. (2012). The Price of Inequality: How Today's Divided Society Endangers Our Future. New York: Norton.

The World Bank (2014). GDP Growth (Annual \%). http://www.worldbank.org/indicator/NY.GDP.MKTP.KD.ZG?page=1

US Government Accountability Office (2007). Housing: Information on Recent Default and Foreclosure Trends for Home Mortgages and Associated Economic and Market Developments. www.gao.gov/products/GAO-08-78R

US Government Recovery Board (2014). Goals of the Recovery Act. Washington, DC: US Government Recovery Board. http://www.recovery.gov/arra/About/GetStarted/Pages/WhatisRecoveryAct.aspx

USA Today (2011). Timeline of Events in the Financial Crisis. http://usatoday30.usatoday.com/money/economy/2011-01-28-financial-crisis-timeline_N.htm

Wilson, J., Tilse, C., Setterlund, D., \& Rosenman, L. (2009). Older People and Their Assets: A Range of Roles and Issues for Social Workers. Australian Social Work, 62, 155-167. http://dx.doi.org/10.1080/03124070902748894

Wollen, B. J., \& Bauer, J. W. (1990). Correlates of Financial Counseling Outcomes: Implications for Practitioners. Families in Society: The Journal of Contemporary Human Services, 71, 148-157. 
Scientific Research Publishing (SCIRP) is one of the largest Open Access journal publishers. It is currently publishing more than 200 open access, online, peer-reviewed journals covering a wide range of academic disciplines. SCIRP serves the worldwide academic communities and contributes to the progress and application of science with its publication.

Other selected journals from SCIRP are listed as below. Submit your manuscript to us via either submit@scirp.org or Online Submission Portal.
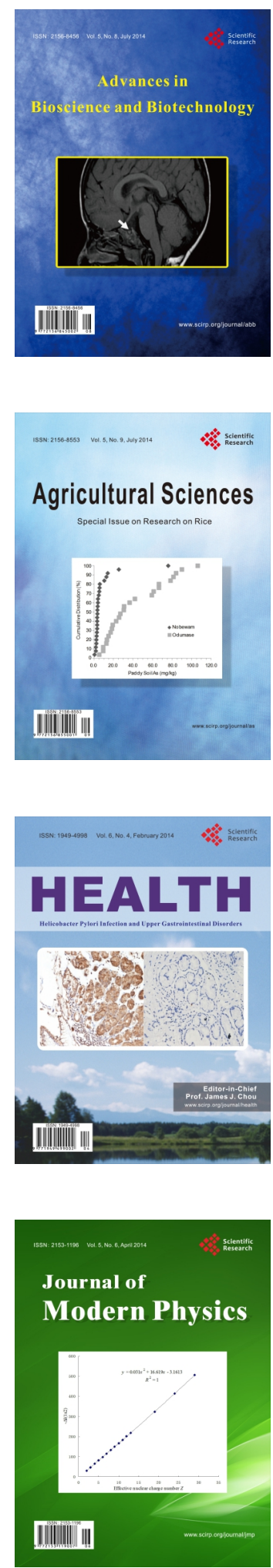
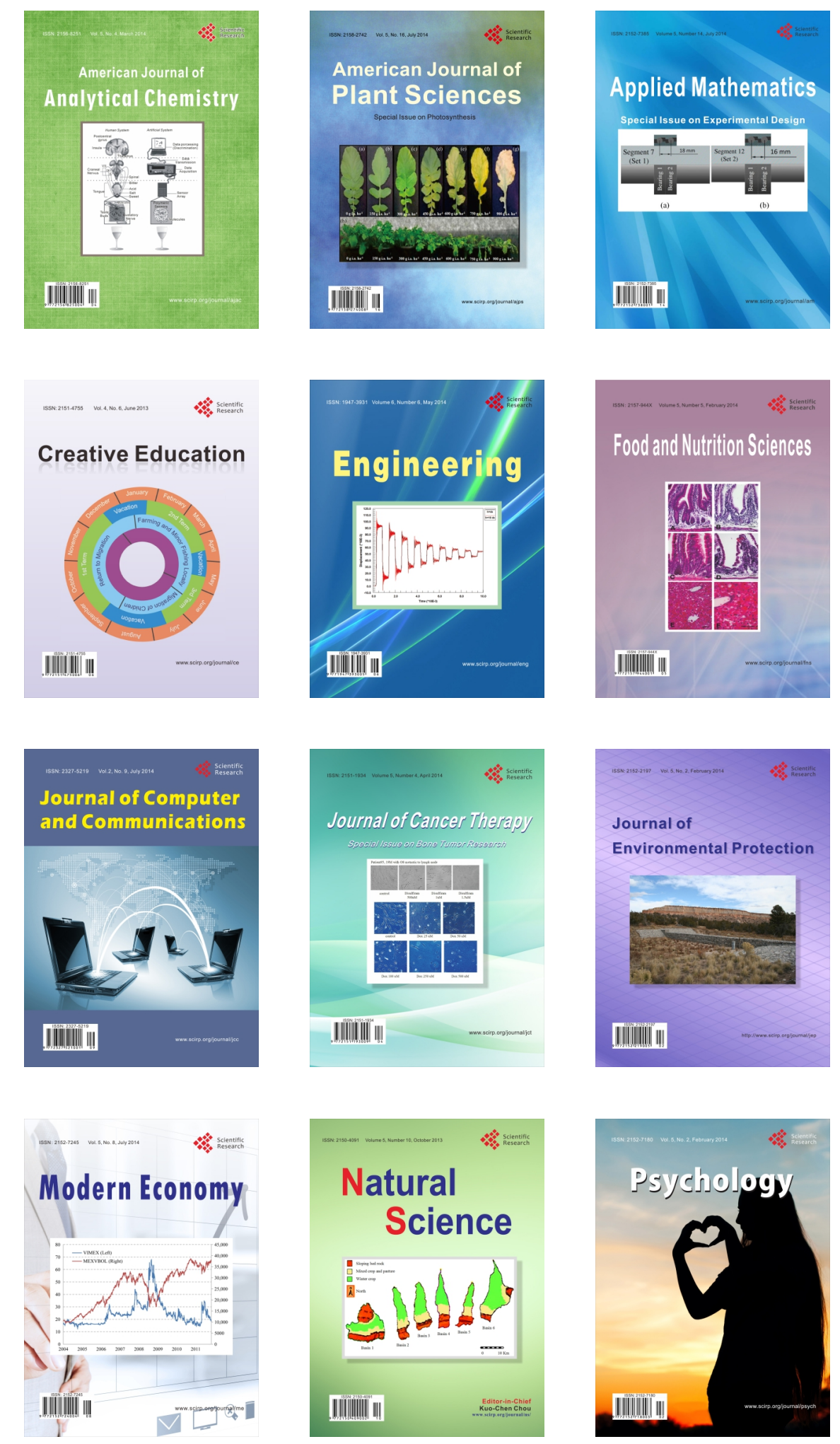